\title{
War Literature: The Kite Runner and What History Cannot Inform
}

Ms. Racha Dayekh*

Department of English, Faculty of Human Sciences, Beirut Arab University, Beirut, Lebanon

DOI: 1 10.36348/sijll.2020.v03i06.004 | Received: 06.06.2020 | Accepted: 13.06.2020 | Published: 21.06 .2020

*Corresponding author: Racha Dayekh

\section{Abstract}

This paper sheds light on war literature, defining it and highlighting its significance. It also underlines its selective nature as it can magnify, bedim, or even warp certain truths, depending on the perspective from which this literature is delivered. The paper also emphasizes the function of war literature in raising awareness as to the horrors of war and its aftermath as well as its function in promoting peace. Besides, it examines The Kite Runner in this respect. It shows how this novel succeeds in portraying the atrocities of war and its drastic effects long after this war ends. The paper observes how the novel synchronizes the political events with the personal ones in order to show that the war does not only affect those who are directly involved in it but extends to reach the innocent more severely. To underline the parallel between the political and personal events, Husseini employs the rape motif and balances the political turning points with the crucial events at the personal scale. The author also juxtaposes scenes that display the damages of the war with scenes that portray the blissful state before the inauguration of war in order to exhibit the grave impact of war and the irretrievability of this state. Husseini also presents the law of the jungle that becomes prominent during and after the war and exposes the detrimental destruction of the country sites - the destruction that effaces civilizations. The paper also proposes possible topics for future research.

Keywords: War, war literature, Afghanistan war, fact and fiction, psychological trauma, Khaled Husseini, The Kite Runner.

Copyright @ 2020: This is an open-access article distributed under the terms of the Creative Commons Attribution license which permits unrestricted use, distribution, and reproduction in any medium for non-commercial use (NonCommercial, or CC-BY-NC) provided the original author and source are credited.

\section{INTRODUCTION}

War Literature is that which investigates and responds to warfare; it also moves beyond the experience of the soldier at the scene of battle. It provides a broad variety of perspectives on war written in poetry, fiction, and drama.

Despite the huge bulk of war literature that has emerged throughout the history of literature, Lukas [1] states that the more war literature has yet to emerge. He postulates that, although thousands of publications on the war are currently in print, there is a demand for more writing in war, especially creative writing. Broek [2] attributes the reason of this demand to the need of grasping existence in deeper terms and to understand some profound sense of the horror and mysteries contained in war. This associates war literature with the function of giving an honest painting about the war. Bolinger [3] also states that critics have also emphasized an apparent need for the public's greater understanding of the human cost of the war. Thus, the crucial role that war literature plays in revealing some truths about the war is underlined.
Discussing Iraqi war literature, Lan [4] insists that the public, especially the American public, still fails to grasp the staggering tragedy the war has brought on the people. She argues that in spite of television, embedded reporters, and the internet, most Americans are today equally unaware of the horrors that the American invasion has inflicted on millions of Iraqis. . . . With America today in Iraq, the Americans feel there is no need to consider others, no need to contemplate the possibility that they too have lives and hopes, that they too feel pain, bleed, and die. This calls the attention to an essential factor: the side or the point of view from which the story is told, whether it is the victim or the victimizer, the prey or the predator; for there are lots of war literatures that illustrate the misery of the American soldiers in Iraq, depicting them as heroes and as victims and neglecting or ignoring the Iraqis side and their suffering. Lan [4] acknowledges the power of fiction to change a person's social perspective and advocates the mailing of war literature to heads of state and influential politicians, the leaders in particular, who have yet to learn the truths creative writers are expressing in their works of war. These 
truths are, what Christian [5] calls them, the grim realities ignored by most US media discussions of the war.

Bolinger [3] asserts that Literature that makes readers face the victim's side of the conflict is as needed as ever. Lan [4] argues that war literature allows voicing the victims' perspective, because the scene and imagining of the death of others demand writing that pays due witness to that suffering, and to the cost in blood and spirit of endless wars.

Therefore, scholars notice that the victim's side is always left in the dark and that their voice is always hushed out. As a result of this selectivity, the truth is never attained, if not marred in essence. Bolinger [3] emphasizes that everyone needs to see the conflict through a broader scope of human experience: not watching for a mere political message, but to see what such literature may reveal about ourselves, our society, and our existence. Therefore, war literature provokes deep-seated reflections on the war troubling themes. It uniquely voices human existence; it details the widespread and intense trauma in the lives of the victimized people and their bleeding countries.

Lan [4] stresses the fact that war literature is necessary for awakening society to war's horror. It may also function as didactic antiwar rhetoric by stripping naked the horrifying truths about the war. Christopher Barker [6] states that for readers who have never gone to war and who have not been raised on first-hand accounts of war, a literary Virgil can be a useful guide to the difficult questions posed by war. To him, war literature helps frame and analyze the experiences of war, in terms of mortality, trauma, and responsibility. War literature helps understand the massively important human experience of the fear of dying and of violent death. To Alison Johnson [7], this kind of literature shows how the trauma of war can be transferred onto those who do not participate in the war itself. Johnson [7] opines that the traumatic legacy of the war is carried long after the actual war terminates. According to her, war trauma transverses boundaries of generational experience. It touches and equally effects both, those who are actually directly involved, and those who are not; those who witness the period, and those who do not. In essence, the loss of war affects everyone; and that is the striking fact which war literature attempts to show. The trauma of the event passes on to select everyone, rendering them "psychologically a product of the war, its inheritor" [7]; tragically, war integrates all individuals within its framework.

Hinrichsen [8] investigates national and global interpretations and consequences of war and its literature, and states that, in war, "even the most average citizens are part of complex systems of historical remembrance, consumption, and erasure." Thus, everyone becomes equally a prey of war "beyond the contradictions of victory and defeat, life and death" [7]. Typically when authors discuss the transference of trauma, they emphasize how its survivors have passed that trauma onto subsequent generations. Hence, war has the power to shape the consciousness of later generations and communities; the trauma of war is transcribed onto the second-generation individual and, as a result, the war resides within this generation. Gimwood [9] also notes that war literature shows how the trauma of war is transferable to later generations, and Bolinger [3] confirms that, even after war, the violence and threats of violence continue to persist.

Interestingly enough, Janet M. Powers [10] advocates war literature for teaching peace. She states that literature may in fact offer the best avenue to contemplate the realities of war. For her, war literature examines the realities of war rather than buying into the platitudes of political leaders who extol sacrifice and justify revenge. Powers [10] states that the art of war literature is not of recent birth; and she gives an account of war in the classic epics - The Illiad, The Odyssey, and The Mahabharata - and how they speak eloquently of death in battle, the impact of conquest, and the psychological difficulty of returning home. War literature, she opines, tells the painful story of war refugees and their quest to find a permanent home.

Discussing the blurring line between fact and fiction, Bolinger [3] adopts Tim O'Brien's view, stating that absolute occurrence of the events is irrelevant. $\mathrm{He}$ asserts that what makes an account true is not the physical reality of a narrative-whether the events actually happened or not-what matters is the profound reaction of the audience to a revelation about life and humanity that a mere re-telling of events could not produce. In turning atrocity to a literary episode or in imaginative war writing, John Richardson [11] postulates, there is an attempt to generate sentiments of pity and outrage. Shedding lights on innocent civilian victims, culpable perpetrators, and gratuitous cruelty, and the details of infanticide, rape, and forced spectatorship, although familiar being tackled in newspapers, pamphlets, and other journalistic accounts, are portrayed from a humanistic point of view which is obliterated by the objective observation of media and journalism that are mainly concerned with numbers and statistics of casualties. Thus, the function of war literature is to spread awareness about the outcomes of war, to delineate and display the trauma of the victimized people with all its agonies, agitations, and perpetual traces. Therefore, what matters is not that war literature memorializes history, rather it is that it examines the unique themes surfacing in the war era: the portrayals of war, the conceptions of identity, the reactions to and depictions of the Other, and the possibility of recovery - both physical and emotionalfrom the war, to name a few. 
Overall, The Kite Runner is a story that traces the maturation of Amir, a boy from Afghanistan, and his struggle to overcome the aftereffects and fallout from a series of traumatic childhood events, in which war has a hand. Although the story is not merely about war, its being told against the devastating backdrop of the history of Afghanistan over the last thirty years, the novel becomes a witness to the fact that war is internalized into the consciousness of the people concerned whether intentionally or unawares. Consequently, the novel becomes a witness to the fact that even when people are not involved in the act of war, the war eventually will stretch its hands and include them in its circumference. The story of Amir is narrated at the time of the tumultuous events, from the fall of Afghanistan's monarchy through the Soviet military intervention, the departure of refugees to Pakistan and the United States, and the emergence of the Taliban regime. In Jackson's words [12], The Kite Runner "paints a sometimes painful and sometimes poetic picture of life in Afghanistan from the fall of the monarchy in the 1970s through the Soviet invasion and into the era of the rise of the Taliban". Thus, the novel situates the trauma of war as a background of the community in general and the characters of the novel in particular. It interrogates the inherent effects of the war; it powerfully raises questions on the practices of those involved and highlights how violence is exported to the victimized countries and brought home to be excessively nourished even after the attack ceases.

\section{Analysis}

The story recollected starts before the first spark of war, when Afghanistan was still calm and peaceful. Amir's life then was going smooth, and his friendship with Hassan, the servant's son and a Hazara member - though he would not call it friendship - was at its best, filling his life with happiness. Then the events of the action inaugurate with the fall of the King, when, in Amir's words, "Afghanistan suddenly changed forever" [13]. That night was the beginning of the end of the Afghanistan they knew. It all happened when they heard shootings and explosions and shattering of glass. This conscious interweaving of the condition of Afghanistan and Amir's life is telling. Narrating his story in retrospect, Amir is totally aware that what was happening in Afghanistan was paralleled by the agitations that were occurring simultaneously in his life. Amir contemplates, "none of us had any notion that a way of life had ended" [13]. This shows the drastic change that was bound to happen at all levels. The king was overthrown by his cousin. The monarchy was terminated. This marked the first spark in the train of agitations that was yet to arrive. The overthrowing of the king intensified the rupture in Afghanistan society and commenced a fierce irreparable fissure between the people of the same country, the Pashtuns, to which Amir belongs, and the Hazara, Hassan's caste. As a result, the chaos that ensued was an opportunity to some of the Pashtun's, who wanted to "rid Afghanistan of all the dirty, kasseef Hazaras" [13]. Not only this, but also just as it was the first dreadful blow for Afghanistan, so was it for Hassan, because "that was the winter that Hassan stopped smiling" [13]. This parallel drawn between the agitation in Afghanistan on one hand, and the life of Amir and Hassan on the other, pervades the novel, where the common process of devastation embracing both is intensified. The trepidations ensued in the country, as well as in the lives of the characters, who were plunged into even greater turmoil.

If the dethroning of the king is the catalyst of action at the political level, then on the personal level the main instigator of all the events to come is the kitefighting tournament. Interestingly, the kite-fighting tournament is described in terms of war imagery. In Kabul, fighting kites was a "little like going to war" [13], it was "a battle"; the kite was a "gun" and the kite cutting line was the "bullet". The cheering of the audience was likened to that of the "Romans chanting for the gladiators to kill, kill!" [13]. The tournament was indeed a battle, and the kite was definitely the bullet turned against Hassan and tearing the two friends both psychologically and physically. The kite was the main reason behind Hassan's rape. Hassan ran to claim that kite for Amir, got trapped by three bullies in a blocked alley. Because he refused to hand them the kite, he was raped under Amir's witnessing eyes. The incident cut deeply through each and between them, Amir for betraying his friend and not going to his rescue, and Hassan for both, being betrayed by his friend and being the victim of rape. What is noteworthy is that while giving the account of the rape scene, Amir also recalls the incident of the overthrowing of the King. This analogy highlights the fact that the interrelatedness of the events in Afghanistan and those of Amir's life is not arbitrary. The rape of Hassan metaphorically stands for the rape of Afghanistan and for the victim's being betrayed by those who are mostly close to the them. The king was overthrown by his cousin; this fight for the rule and the betrayal is mirrored by the first act of betrayal of Hassan by Amir, and by the boys of his country. Although Hassan, who is "incapable of hurting anyone", has "never denied [Amir] anything" [13] and has saved him from bullying, Amir chooses not to rescue Hassan and to witness his rape, acting later as if he has seen nothing. Rape is not just physically violent, but it is also an attack on the victim's emotions and dignity. Rape in this sense represents complete physical and mental domination of those who do not have power by those who do. The motif of rape persists throughout the novel, metaphorically demonstrating the country being assaulted by the Soviet forces, and later by the Taliban. This motif, therefore, dramatizes the fact that eventually the violence inflicted upon the people of a certain country is internalized into those people who, in turn, wage war against their own people. Baba anticipates this and says to Amir "God help us if Afghanistan falls 
into their hands" [13], meaning Taliban, the Islamic radicals that eventually seize the control in Afghanistan. What accentuates the assumption that the rape of Hassan is synonymous with the assault of Afghanistan is that Amir envisioned Afghanistan in Hassan's aspect: "to me, the face of Afghanistan is that of a boy with a thin-boned frame, a shaved head, and low-set ears, a boy with a Chinese doll face perpetually lit by a harelipped smile" [13]: this is Hassan's face. The rape happens and the fissure is cracked.

Whenever Amir mentions a turning point in his life, unawares, he brings Afghanistan into light: "I TURNED THIRTEEN that summer of 1976, Afghanistan's next to last summer of peace and anonymity" [13]. It was at the same time that Amir framed Hassan in the act of stealing and, as a result, Ali and Hassan deserted Kabul altogether. Amir thought that by sending them away, he would spare his conscience the assault of and entrapment by guilt and he would be able to rest. However, just like the case of Afghanistan, Amir was deprived of his peace.

Although the major events of the novel trace the context of Amir's life, they also transcribe Afghanistan's political transitions as well. The narrative shifts in time and marks the change of the calm state of Kabul during the monarchy, to the founding of the republic, and then it sheds light on the Soviet invasion and the infighting between rival Afghan groups ruining the country. After relating Ali's and Hassan's departure, Amir then shifts directly to five years later, where the integration of the war in Afghanistan with his life becomes clearer and sharper. Kabul changed in the five years that elapsed. The communist left in Afghanistan overthrew President Daoud Khan. The coup created a split in Afghan society that led to numerous executions and widespread paranoia. The Afghans were encouraged or compelled to turn in anyone who might be an enemy of the ruling faction. People turned against one another. This led to an invasion by Russia at the end of 1979, thrusting the country under a traumatic devastation. As result of this invasion, Amir and Baba attempted to flee to Pakistan from this situation. The war and the political events, therefore, have a hand in deciding the novel's plot and dictate significant effects on the lives of the characters involved, becoming a chief player in the lives of the characters. Amir now got into the war scene and started experiencing the suffering of the victimized citizens, who were struggling to cope with the immediate concussions from the disaster.

Amir describes the plight of the refugees of which he was now part and parcel, as they all escaped, smuggled, in the back of a truck, from Kabul, which was invaded by the Soviets and had become a warzone. Not only was the journey hellish, but also, Amir remembers, people could not trust one another anymore. Anyone would sell the other out of fear or for money. The war has inflicted an irreparable cleft between people: "people told on each other, neighbor on neighbor, child on parent, brother on brother, servant on master, friend on friend" [13]. The "rafiqs" have turned everyone into a potential spy in the eyes of the other, splitting Kabul asunder. This boldly illuminates the shifting loyalties among the people as a result of war. Amir, in short, was imbibing the stress and agitations of the war. He gives a detailed account of the Russians soldiers patrolling the sidewalks, the tanks rolling up and down the streets of his city, and the turrets swiveling like accusing fingers, the rubble, the curfews, the Russian Army Personnel Carriers weaving through the bazaars, and the deafening roar of $\mathrm{MiG}$ over their heads. Amir speaks of it as a nightmare from which he, hopefully, would soon wake up. He also touches upon the corruption that smeared the afghan soldiers, who, together with the Russian soldiers at the checkpoints, had set up a "mutually profitable" arrangement, extorting the refugees and exploiting their need for shelter. War, in short, has ruined the rule of law, rendering chaos and corruption the supreme rulers.

Again, soon after this detailed account of the war scene, the rape motif surfaces again, when the Russian soldiers at the checkpoint demanded half an hour with the woman on the truck as a price to let them pass. Simultaneously Hassan's rape is brought into light again. Amir remembers how Baba was willing to sacrifice his life to keep the Russian guard from raping the woman with them. To Baba, in saving the honor of this woman, he was trying to preserve the honor of not just one person, but of all of Afghanistan. It is not, therefore, a coincidence that the rape is interwoven with the assault on Afghanistan. The rape is a metaphor for the rape of the land itself.

Further, after the horrific journey, the refugees stayed for a week in a rat-infested basement, which displays the humiliation the refugees suffered in their home country. Again, rape reappears; this time with Kamal, whose father tells Baba about the rape incident and Amir eavesdrops some of the words and is able to comprehend what has happened to Kamal. Moreover, to sharpen the sense of their destitute condition, the author juxtaposes these scenes of frustration with those of Kabul before the savage foreign hand took control - a paradise-like country with green grass, tress, and laughter. The memory was, just like Amir described it, "a brushstroke of color on the gray, barren canvas that our lives had become" [13]. Their lives had become worse than lifelessness. It is a pricey war, like all wars. Amir recounts the rest of their ride as glimpses of horrific remembrances: "MiGs roaring past overhead; staccatos of gunfire; a donkey braying nearby; the jingling of bells and mewling of sheep; gravel crushed under the truck's tires; a baby wailing in the dark; the stench of gasoline, vomit, and shit" [13]. These remembrances highlight the vehement impact of war on the life scene of Afghanistan. 
The narrative shifts again to the 1980s, when Kabul's destruction forced Baba and Amir to leave the east altogether, with all their possessions left behind, and flee to California, America, the safer part of the world. Being impoverished, stripped of all their past wealth, their condition in America did not get the least better. They carry with them the trace of war - their impoverishment. They were transferred from having wealth and a position of power to having to work in humble job at a gas station and living modestly. Amir recollects the state of his father who, after being used to the peace and luxury of the past life, now had to work in anything to fend for himself and his son: "his nails chipped and black with engine oil, his knuckles scraped, the smells of the gas station--dust, sweat, and gasoline-on his clothes"; accentuating his father's wretched status is the juxtaposition of the current condition of his father with the old times of the wealthy sugarcane fields of Jalalabad and the gardens of Paghman, of people milling in and out of his house, of walking down the bustling aisles of Shor Bazaar and greeting people who knew him and his father, knew his grandfather, people who shared ancestors with him, whose pasts intertwined with his. War, therefore, had consumed all that was and left nothing. Their peaceful past was forever effaced. All that was left was the agonizing present.

War and Afghanistan recede to the back while the reader traces the life of Baba and Amir in America, their suffering, Baba's lung cancer, the marriage of Amir to Soraya, and finally Baba's death. Then Afghanistan appears again with another turning point of Amir's life. "IN THE SUMMER of 1988, about six months before the Soviets withdrew from Afghanistan, I finished my first novel"; this shows how his country and the war are always residing in his memory; and that the episodes of his life are intricately wed to those of his home land. This is also evident in his recollection that his novel was released in the year that the "Shorawi completed their withdrawal from Afghanistan" [13]. Amir contemplates that it should have been a time of glory for Afghans. However, the war raged on, this time between Afghans, the Mujahedin, against the Soviet puppet government of Najibullah, and Afghan refugees kept flocking to Pakistan. Hence, as Amir relates events from his life, his mind often ponders and the readers themselves simultaneously trace events on both levels, the personal and the political/national.

The war is brought to focus again when Amir leaves America to meet his father's friend, Rahim Khan, in Pakistan. Rahim Khan's voice takes over and he recounts to Amir what had become of their town in the latter's absence since the Taliban took over. Rahim Khan tells Amir the story of how he got the scar over his eye. At a soccer game, a man next to him cheered loudly. The guard on patrol heard the noise, walked towards them, and smashed Rahim Khan with the butt of his rifle. This brief incident demonstrates how violence was enthroned a ruler, Taliban being the agents. He also tells Amir about the devastation in Kabul. He says things only got worse after the Soviets were forced out and Taliban took over. Their conversation touches upon what Afghanistan had become since the Taliban assumed control. He tells him that Kabul became dangerous as the brutal fighting between Afghan factions over control of the city grew worse. Homes were destroyed and civilians killed by random rockets. Kabul was torn among different factions. If one attempted to move from one part of the country to another, one risked getting shot by a sniper or getting blown up by a rocket. Thus, people dug holes in their walls and tunnels underground, so they could bypass the dangerous streets. Rahim Khan reports to him the atrocities of war: "People were so tired of the constant fighting, tired of the rockets, the gunfire, the explosions, tired of watching Gulbuddin and his cohorts firing on anything that moved" [13], people were so tired that they celebrated when Taliban rolled in and kicked the Alliance, thinking their salvation got near. It was totally the opposite. The war had changed the face of their home town, that it estranged its own people. Rahim khan recollects how he stopped going to Kabul because there was "No one to greet, no one to sit down with for chai, no one to share stories with, just Roussi soldiers patrolling the streets", for everyone fled. Hosseini, [13] this is all because of the shorawi, "may they rot in hell for what they did to our watan" [13]. What is worse, and to the distress of Amir, is that the arms of war extended to claim Hassan's father's life when he stepped on a land mine. War separates and memory struggles to keep hold on what it yearns to cherish. Amir struggles to invoke the image of Ali's face, in vain: "I tried to conjure Ali's frozen face, to really see his tranquil eyes, but time can be a greedy thing--sometimes it steals all the details for itself' [13]. He tries to cling to this memory so he can envision that familiar face, which was part of his heavenly childhood; due to the fallibility of memory, he finds that what was once real is now a mirage and his mental pictures fail him.

Through Rahim Khan's eyes the reader sees the turmoil that Afghanistan passed through. By 1995 the Shorawi were defeated and long gone and Kabul belonged to Massoud, Rabbani and the Mujahedin. The infighting between the factions was fierce and no one knew if one would live to see the end of the day. People's ears became accustomed to the whistle of falling shells, to the rumble of gunfire; their eyes got familiar with the sight of men digging bodies out of piles of rubble. War turned Kabul into hell on earth. Taliban destroyed the orphanage and the cinema park, and banned kite fighting. Two years later, in 1998, "they massacred the Hazaras in Mazar-i-Sharif" [13].

Wars claim the lives of the innocent. That war claimed Hassan's life and his wife's. The Taliban went to Baba's house and shot Hassan and Farzana and sent 
Sohrab to an orphanage. The account of the turmoil that Afghanistan was subjected to is further emphasized in Hassan's letter that he wrote to Amir before he died. Hassan wrote that the Kabul they used to know is forever effaced:

"Alas the Afghanistan of our youth is long dead. Kindness is gone from the land and you cannot escape the killings. Always the killings. In Kabul, fear is everywhere, in the streets, in the stadium, in the markets, it is a part of our lives here, Amir agha. The savages who rule our watan don't care about human decency . . . The streets are full enough already of hungry orphans and every day I thank Allah that I am alive, not because I fear death, but because my wife has a husband and my son is not an orphan" [13].

His letter portrays a sincere painting of what change the war effected. The civilians were killed and aggression rules mercilessly. The fear of being killed and leaving his family without a protecting man kept haunting Hassan as he always thanked his God that he was still there for them. However, just as the war claimed Ali's life in the mine explosion, so did it claim Hassan's. Taliban has shot him and his wife for being Hazaras. The Taliban went to Baba's house and found Hassan and his family there. Hassan tried to defend himself, saying that he was taking care of the house for a friend, and they called him a liar like all Hazaras. They forced him to kneel in the street and shot him in the head. When Farzana ran out of the house to see her husband, they shot her, too. Amir imagined time and again how the scene had happened: "a man dressed in a herringbone vest pressing the muzzle of his Kalashnikov to the back of Hassan's head. The blast echoes through the street of my father's house. Hassan slumps to the asphalt, his life of unrequited loyalty drifting from him like the windblown kites he used to chase" [13]. Then Taliban moved into Baba's house. The war transformed the Taliban into conquerors and invaders in their homeland.

This horrific scene that Amir recalls is woven with the once sweet past of him and Hassan flying kites. This is done to accentuate the terrible present, the effects of the war, and the intense impact of Hassan's death. It is also done to illustrate the weighty sense of guilt that kept haunting Amir ever since he betrayed his "relentlessly loyal" childhood friend, who was first raped to secure Amir's kite, and then persecuted while protecting Amir's house. Consequently, Taliban occupied the house. Hassan's death is underlined as a combination of the political strife ravaging Kabul and the bias against the Hazaras that is highlighted repeatedly in the novel. The two members of the Taliban who shot Hassan and Farzana were left unpunished for their crime. This suggests that the lives of Hazaras are valueless, or at least have not enough value to punish anyone who chooses to terminate these lives.

War novel attempts at illustrating the war with all its ingredients. Another specimen of the victim of war whom Amir encounters is embodied in Farid who drives him to Kabul. Farid and his father joined the jihad against the shorawi until "helicopter gunfire had torn the older man to pieces" [13]. Two girls of his were caught in a land mine, the explosion that severed toes from his feet and three fingers. Farid and his family are an embodiment of the difficulties that many Afghans faced in the years of warfare that brutally ravaged the country. War kills, and war mutilates; war distorts, and war deforms. This is a preliminary to Amir's ultimate confrontation with the dilapidation of his country. Crossing the border to Afghanistan in quest of Sohbar, Hassan's son, Amir confronts the atrocities of war in person. Marks of poverty were everywhere. The city was populated with beggars and littered with rubble. There were ruined Chains of little villages here and there, like discarded toys among the rocks, and broken mud houses and huts consisting of little more than four wooden poles and a tattered cloth as a roof. In a scene that vividly depicts Afghanistan's wretchedness, Farid points out to Amir one man trying to sell his leg to another man, who bargains with him over the price. There are few real signs of life left, made clear by the fact that not even trees remained, yielding a terribly desolate landscape. They also saw children dressed in rags chasing a soccer ball outside their huts, homes had been reduced to roofless walls and piles of twisted clay. Definitely, it is not his once country. This fact is consummated by Amir's exclamation: "I feel like a tourist in my own country" [13]. War has distorted the features of his country that he fails recognize it now. His sense of rootedness is now terribly shaken. When they resume their ride, Amir gives an account of the "grim reminders" of the war, strewn along the road: "burned carcasses of old Soviet tanks, overturned military trucks gone to rust, a crushed Russian jeep that had plunged over the mountainside" [13]. There were times in Afghanistan when the dead were luckier than those who were alive. This sums up the wretchedness of Afghanistan caught up in savage war.

The role war has in destroying the features of a country and in effacing its civilization is underlined by Amir's retort to the lawyer when the latter tells him that orphans should be kept in their own country so their heritage can be preserved: "What heritage? The Taliban have destroyed what heritage Afghans had. You saw what they did to the giant Buddhas in Bamiyan" [13]; and it is also highlighted by Amir's first impression upon entering the country and his exclamation that he must have entered the wrong country: "When Kabul finally did unroll before us, I was certain, absolutely certain, that he had taken a wrong turn somewhere" [13]. Kabul was swarming with children beggars and their mothers; and Amir contemplates the bitter reality 
that "the wars had made fathers a rare commodity in Afghanistan" (20). This is another condition that the war effects - fatherless families and shattered orphans. Thus, the author does not casually mention Hassan's death leaving Sohrab fatherless; rather, he emphasizes this consequence of war by highlighting the rarity of fatherliness in the country. Amir goes on to enumerate the hallmarks of the old Kabul that the war destroyed: the old city wall, the Bala Hissar Fort - the ancient citadel, the shops and hotels, neon lights and restaurants. This strategy of invoking the past to evaluate the presence is frequently repeated to sharpen the immense effect of war. Now the site has completely transformed into a "giant castle of sand" with collapsed buildings and barely standing walls pierced with rockets shells. Entire blocks had been obliterated to rubble.

Again when Amir reaches his father's house, he instantly juxtaposes scenes from the beautiful old past with that of the terrible present; this is done only to underscore the enormity of the impact of war on the house and, in turn, to highlight his sense of estrangement and nostalgia that this impact has engendered in him. When he notes how the brutality of war has destroyed the place, he bitterly contemplates: "I stood outside the gates of my father's house, feeling like a stranger" [13]. Not only is he estranged from his homeland, but he is also equally alienated from his own home. This is absolute alienation. It does not differ from displacement, as his country and his house have completely metamorphosed to a different country and a different house. The after-war country estranges its own people and alienates them generating in them the lack of the sense of belonging. Farid confronts him with the bitter reality that sums up the horror of war: "Nothing that you remember has survived" [13]. Not only does war assault the country, it also extends itself to enfold the memory with portending oblivion. Eventually war effaces all, blurring the memory that fades with the fading features of the country. The devastation of the present Afghanistan is strikingly symbolized by the pomegranate tree under which Amir and Hassan used to spend their childhood playtimes. Now after all that has happened, Amir and Farid visit it and notice that it is barren. Just as the Kabul they once knew no longer thrives, so is the tree lifeless. Thus, the fruitless tree echoes the condition of Afghanistan and its miserable futile condition in which the country is thrust.

An additional and equally important terrible fact concerning the effects of war that the novel unveils is that when the primal assaulter withdraws, people are set against each other, and those in power practice worse deeds in dealing with the people of their own country than the deeds of the outsiders. They reintegrate themselves in the war and enact it upon the weaker or the helpless that are eventually scarred not only physically but psychologically. The ascent of the powerful to rule evokes the law of the jungle. The powerful prey on their own fellow citizens; they wage aggressive war against each other. When Amir goes to claim Sohrab from the orphanage, he finds out that the Taliban official has taken him, or, rather, bought him, a month earlier. Amir traces the Taliban office and alights at the stadium where he witnesses another horrifying scene executed by the Taliban. He sees Taliban members in red pickups drive into the stadium. They unload a blindfolded man from one truck and a blindfolded woman from the other and bury each up to the chest in a hole on the field. They stone them to death in the pretext of executing God's law. The Taliban group has created simply a mask to hide behind or a means for them to justify their violence and authoritarian rule - the fulfillment of God's law. Violence and murder plague the atmosphere under the name of Islam. This unveils the brutal practices of the people in control and their thirst for violence and death. Amir continues to the Taliban office, only to see Sohrab wearing a blue silk outfit and mascara, appearing more feminine and suggesting that the men have sexually manipulate him. Amir discovers that the Taliban official from whom he must rescue Sohrab, and who stoned the man and the woman, is no one but Assef, the same exact person that raped Hassan years ago. When Assef, who sexually abuses the children of the orphanage and who performs savage practices with his country people, speaks about the "mission" he has to accomplish, Amir blurts: "Stoning adulterers? Raping children? Flogging women for wearing high heels? Massacring Hazaras? All in the name of Islam?" (Hosseini, 2001). This sharply delineates that the war enthrones the powerful, who, then, inflict violence upon the weaker souls. The establishment of the republic gives Assef the opportunity or the privilege to harass Amir and Sohrab, simply because Assef's father knows the new president. He takes advantage of the social order because he occupies a position of great power. The corruption that the war breeds is unlimited. Assef's position allows him simply to indulge his sexual urges without the fear of paying the penalty. In other words, the ascent of the powerful to the rule evoked the war's effecting Darwin's law of the jungle - the survival of the fittest.

Besides erasing landmarks, breeding further aggressions, estranging people from their homeland, and leaving most of the families fatherless and unsheltered, war also has an upper hand in snatching children of their childhood. As a consequence of War, the peaceful lives of children are stolen, and they are exposed to a horrible experience which matures them beforehand. This is registered in Sohrab's plea, "I want my old life back" [13]. The novel sheds light on this tragic reality; Amir recalls a line he thinks he has read or heard before: "There are a lot of children in Afghanistan, but little childhood" (Hosseini, 2001). He remembers this line while observing Sohrab as he examines his own photograph with his parents whose lives the war has snapped. By putting this line into another person's mouth, the author deems this fact 
collective; not only Sohrab's childhood has been robbed, but also the childhood of all the children in Afghanistan. This brings into mind both Johnson's [7] and Bolinger's [3] statements that even when the war desists, its effects extend to reach those who are not involved; it extends to envelop later generations. Besides, it only does this by making sure it has agents that would carry out the same, if not worse, deeds as the primal assaulter - the agents being the countrymen themselves. Amir sheds the light on this bitter fact when he states that his "chest tightened with a surge of unexpected anger at the way my countrymen were destroying their own land" [13].

The aftermath of war is equally if not more horrific than during the war itself. Foreigners leave the country in the hand of those who ruthlessly wage war against their own people. That is implied in the lawyer's statement to Amir: "In the aftermath of [the] disaster . . . the Taliban are a disaster" [13]. The country sinks in quick sand and they make it impossible for one to repair any damage. It obliterates the humane side of humanity - the fact which crowns Rahim Khan's statement: "They don't let you be human" [13]. They simply entrap man in a vicious circle.

Finally, Amir shifts to the war that followed the September 11 attacks. This is done to mark a turning point in Afghanistan, when the USA forces inaugurated their war against the Qaida in Afghanistan. By the same token, it registers a turning point in Amir's life. After the agonizing experience that Soharb went through, he lived with Amir and Soraya in complete withdrawal, in utter silence. "He didn't so much live with us as occupy space. And precious little of it" [13]; and it was not the silence of quietness, peace, or tranquility. He was silent and irresponsive that other people hardly seemed to notice him, "like he wasn't there at all". It was the silence of someone who has "taken cover in a dark place, curled up all the edges and tucked them under". Sohrab inherited the stress of war; and war trauma wrote itself onto his fragile identity that seemed to be at the verge of dying out in silence. He was an embodiment of the unspeakable pain. Then, on those days that marked the American bombing of Afghanistan, in the park, Amir got the chance to fly a kite for the first time since 1975 and all the hectic years that followed; and Sohrab was watching him. Amir defeats the opposing kit-runner. Sohrab smiles. Amir asks him whether he wants to run the kite for him. Sohrab nods, and Amir replies, "for you, a thousand times over", and runs.

This marks a note of hope that despite all the tragedy inherent in war and its aftermath, there would always be that glimpse of possibility to make amends to the wounded country. At the night when Amir imagines the scene of shooting Hassan by the Taliban, Amir dreams of a man shooting Hassan, and he realizes he is the man in the dream. This registers the guilt Amir feels for betraying his own friend, and brother, Hassan. Because from the very beginning Hassan's face was associated with Afghanistan, then the motif of betrayal of Hassan by Amir and of Ali by Baba delineates the country being betrayed by its own civilians. If Amir saves Sohrab, both he and Baba will be pardoned, and perhaps the redemption act of adopting Sohrab into his secure life is the wish to redeem Afghanistan. Running is symbolic; it is an act of liberation. Would Sohrab's wounds leave permanent scars? Would his trauma be life-long? Would he be forever buried and haunted by an unbearable past? Would he eventually be able to undo all the injuries inflicted upon him by the one monster - war? Another curious question is also raised: Wahid invites Amir to write about Afghanistan and to "Tell the rest of the world what the Taliban are doing to our country" [13]; and Amir does reproduce his experience. Dominick LaCapra [14] opines that the victims of war, in order to cope with their trauma that results from war - whether direct or indirect victims have the tendency to either act out, that is to "repeat something compulsively", or to "work through" it. When acting out trauma, victims immerse themselves in the past, "as if one were still fully in the past, with no distance from it; and to work through, and this is a desirable process" - a process in which "the person tries to gain critical distance on a problem and to distinguish between past, present, and future. It requires going back to problems, working them over, and perhaps transforming the understanding of them. By rewriting his experience in retrospect Amir tries to create a measure of detachment from the past. The question is: Is Amir's act of writing itself an attempt on his part to liberate himself of the agonizing past, to extricate himself of the guilt, to empty himself of the relentlessly lingering past, an attempt to close the book and seek a better future in Sohrab? Who knows?!

\section{CONCLUSION}

The Kite Runner provides a brief macabre glimpse into this violent world; it provides some insight as to what happens in as well as after war. It shows the terrible instabilities that accompany war and how people die a needless death. It shows how unqualified people gain power because of the changing political climate. It shows how the weight of the War's trauma transverses the boundaries of direct participants, and is carried over to the innocent individuals, the real victims of an unjust war. War literature highlights the sacrifice and sharp grief that characterize all wars; and it surely evaluates the price of war. The Kite Runner Does it all.

\section{Further Study}

The Kite Runner lends itself to many disciplines. Attention might be called to its intertextual references. One example might be in chapter four where Amir relates the first story that he writes: "a man whose "tears turned into pearls" - the image that echoes a similar one in Shakespeare's The Tempest. Besides, the prominent presence of Afghanistan in general and of 
Kabul in particular, makes the portrayal of the "city" in the novel and what it represents a tempting approach. The heritage of Afghanistan is disseminated throughout the novel, and the minutest details about Afghani life are lent a vast space in the novel that invites meticulous examination of its heritage and makes it a future possibility for further research. Examples of the heritage of Afghanistan embrace Buzkashi tournament in chapter three, the caravan, the myth of shahnmah , and the conventional words mashallah, inshallaha in chapter four, the traditional tabla and harmonium, the fortune teller in chapter seven; also Amir's description of Yelda which he associates with his first love: "In Afghanistan, _yelda_ is the first night of the month of _Jadi_, the first night of winter, and the longest night of the year". An additional example is their conception of "honor" and "pride" - "Nang" and "Namoos", and their attitude towards gender: "I was fully aware of the Afghan double standard that favored my gender" (Hosseini, 2001); and, finally, the Afghanian rituals like "lafz, the ceremony of 'giving word", the "zakat", the "hadj", and the "Koran" in chapter three, the "namaz" in chapter four, Eid AlAdha, or Eid-e-Qorban in chapter seven. Furthermore, because The Kite Runner is narrated as a process of recollection, "memory" would also be a potential future investigation. At the outset of the novel, Amir starts thus: "That was a long time ago, but it's wrong what they say about the past, I've learned, about how you can bury it. Because the past claws its way out. Looking back now, I realize I have been peeking into that deserted alley for the last twentysix years." The novel is also pregnant with dreams, and this makes the function of the dreams in contributing to the meaning of the novel another study. Finally, the archetypal figures and their shadow phases would also be an interesting study.

\section{REFERENCES}

1. Lukas, M. D. (2010) Workshopping the Next Generation of American War Literature. Virginia
Quarterly Review Online, The University of Virginia, 86(2).

2. Broek, M. (2011). The MFA At War: Proximity, Reality, And Poetry in Brian Turner's Phantom Noise. American Poetry Review, 40(5).

3. Bollinger, L. (2014). A Broader Scope. WLA. 26.

4. Lan, M. (2009). Mark Twain's 'The War-Prayer': Reflections on Vietnam And Iraq. Journal of Transnational American Studies, 1(1).

5. Christian, C. (2007). What About the Iraqis? The New York Review of Books.

6. Barker, C. (2014). Hemingway's Death in the Afternoon and the Fear of Death in War. WLA. 26.

7. Johnson, A. (2014). Sam Hughes as a Second Generation Trauma Victim in Bobbie Ann Mason's In Country. WLA. 26.

8. Hinrichsen, L. (2008). 'I can't believe it was really real': Violence, Vietnam, and Bringing War Home in Bobbie Ann Mason's In Country. Southern Literary Journal, 40(2).

9. Grimwood, M. (2007). Holocaust Literature of the Second Generation. NY: Palgrave Macmillan.

10. Janet, M. P. (2007). Teaching war literature, teaching peace. Journal of Peace Education. Gettysburg College, Gettysburg. USA. 4(2):181191.

11. Richardson, J. (2009). Atrocity in mid-eighteenth century war literature. Eighteenth-Century Life. Duke University Express. 33(2);92-114.

12. Jackson, J. E. (2015). Reflections on reading. Naval War College Review, 68(2), 149. http://libproxy.csun.edu/login?url=http://go.galegr oup.com.libproxy.csun.edu/ps/i.do?id=GALE\%7C A $412410929 \& v=2.1 \& u=$ csunorthridge \&it $=r \& p=I$ TOF\&sw $=$ w\&asid $=7060 \mathrm{~d} 7 \mathrm{a} 1 \mathrm{de} 09 \mathrm{f} 34 \mathrm{f} 87 \mathrm{~b} 1 \mathrm{a} 2 \mathrm{fc} 65$ $8 \mathrm{c} 4505$

13. Hosseini, K. (2003). The Kite Runner. USA: N.Y. Penguin Group.

14. LaCapra, D. (2001). Writing History, Writing Trauma. Baltimore: The Johns Hopkins UP. 